Hanna Kostyło*

Bydgoszcz

\title{
Refleksja jako podstawa podmiotowości według antropologii Paula Freirego
}

Paulo Freire był brazylijskim pedagogiem, twórcą i najwybitniejszym przedstawicielem tak zwanej pedagogiki emancypacyjnej. Żył w latach 1921-1997, w okresie, w którym dokonywały się głębokie zmiany społeczne i polityczne w jego rodzimej Brazylii, a także ważne zmiany kulturowe w krajach rozwiniętych. We wszystkich tekstach odnoszących się do biografii Freirego podkreśla się jego głębokie, intelektualne osadzenie w tradycjach personalistycznej oraz marksistowskiej. To połączenie wrażliwości właściwej dla otwartego katolicyzmu z przekonaniem o klasowej strukturze społeczeństwa i konieczności zmiany tej struktury zbliża Freirego do wpływowego nurtu we współczesnej teologii, tak zwanej teologii wyzwolenia. Koncepcję brazylijskiego pedagoga nazywa się często pedagogią wyzwolenia. Próba połączenia podejścia chrześcijańskiego i marksistowskiego była i wciąż jest charakterystyczna dla kultur południowoamerykańskich. W tym sensie myśl pedagogiczna Freirego bardzo dobrze oddaje ducha miejsca i czasu, w których pedagog wzrastał i tworzył.

Dociekania nad pedagogiką i pedagogią Paula Freirego prowadzę już od wielu lat. Opublikowałam kilkanaście tekstów, w których wprost lub pośred-

* Dr hab. Hanna Kostyło, prof. UMK, jest kierownikiem Zakładu Polityki Zdrowotnej i Zabezpieczenia Społecznego w Wydziale Nauk o Zdrowiu Collegium Medicum Uniwersytetu Mikołaja Kopernika w Bydgoszczy. Adres: Wydział Nauk o Zdrowiu UMK, ul. Sandomierska 16, 85-830 Bydgoszcz; e-mail: hanna.kostylo@cm.umk.pl. 
nio nawiązuję do tego nurtu myśli pedagogicznej. W drugim tomie podręcznika akademickiego Pedagogika pod redakcją Zbigniewa Kwiecińskiego i Bogusława Śliwerskiego, wydanego przez PWN, znajduje się rozdział mojego autorstwa pt. „Pedagogika emancypacyjna”, w którym analizuję między innymi pedagogiczne koncepcje Freirego. W innych miejscach uwypuklam związki pedagogiki wypracowanej przez brazylijskiego myśliciela z takimi XX-wiecznymi intelektualistami jak Martin Buber, Theodore Brameld, Ivan Illich czy Noam Chomsky. O pedagogii opartej na myśli Freirego wspominam także w swojej pracy habilitacyjnej poświęconej zasadniczo filozofii i antropologii edukacji Theodore'a Bramelda. Pokazuję tam, na przykładzie programów alfabetyzacyjnych realizowanych w latach 70. i 80. w Stanach Zjednoczonych, trudności związane z aplikacją założeń pedagogii Freirego w rozwiniętych społeczeństwach kapitalistycznych ${ }^{1}$.

W niniejszym artykule podejmuję kwestię refleksji jako podstawy podmiotowości, analizując to zagadnienie w świetle antropologii Paula Freirego. Freire podejmował ten wątek w wielu swoich tekstach, przywołując za każdym razem pojęcie budzenia świadomości. Budzenie świadomości jest jednym z kluczowych pojęć wypracowanych przez brazylijskiego pedagoga, obok pojęcia edukacji bankowej oraz edukacji stawiającej problemy. Warto zauważyć, że Freire nie tylko nawiązywał do pojęcia budzenia świadomości, ale dwie spośród swoich książek całkowicie poświęcił temu zagadnieniu. Chodzi o Cultural Action for Freedom oraz Education for Critical Consciousness. Jeżeli mielibyśmy szukać jakiejś tendencji w twórczości Freirego, to wydaje się, że wątek budzenia świadomości pojawia się zdecydowanie częściej w pierwszym okresie twórczości brazylijskiego myśliciela. Jego ostatnie prace, takie jak Pedagogy of the City czy Pedagogy of Hope, nie za-

${ }^{1}$ Porównaj moje teksty dotyczące myśli Freirego, m.in.: „Paulo Freire i jego rozumienie sytuacji edukacyjnej”, w: Nieobecne dyskursy, t. VI, red. Zbigniew Kwieciński (Toruń: UMK, 2000), 215-230; „Dialog Martina Bubera z Paulo Freire”, w: Zaufanie i zrozumienie. Verständnis und Vertrauen, red. Friedrich W. Busch, Piotr Petrykowski (Toruń: Universitas Nicolai Copernici; Oldenburg: Carl von Ossietzky Universität Oldenburg, 2001), 79-87; „Noam Chomsky o antyedukacyjnej funkcji globalnej amerykanizacji”, Forum Oświatowe 2 (2001): 5-32; „Pedagogika emancypacyjna”, w: Pedagogika. Podręcznik akademicki, t. I, red. Zbigniew Kwieciński, Bogusław Śliwerski (Warszawa: PWN, 2003); „Humanistyczne źródła pedagogiki emancypacyjnej”, AUNC. Socjologia Wychowania 360 (2003): 185-196; Rekonstrukcjonistyczne koncepcje zmiany społecznej poprzez edukację. Antropologia pedagogiczna T. Bramelda (Toruń: Wydawnictwo UMK, 2005); „Dwa sposoby (rozumienia) alfabetyzacji”, Kultura i Edukacja 1 (2010): 58-69; „Uniwersalność przesłania 'pedagogii uciśnionych' Paula Freire'go”, Rocznik Andragogiczny (2010): 78-95; „Postmodernizm a utopie edukacyjne”, Kultura i Edukacja 4 (2011): 191-198. 
wierają tak wielu i tak jasnych odniesień do tej koncepcji. Być może powodem było kierowanie tych ostatnich prac przede wszystkim do czytelników amerykańskich, w większości zdystansowanych do analiz marksistowskich, w których koncepcja budzenia świadomości w wyraźny sposób się sytuuje. Jest to jednak tylko przypuszczenie, które wymagałoby dalszych, pogłębionych analiz.

Pojęcie budzenia świadomości jest wyrażane w języku portugalskim jako conscientização, po angielsku - conscientization. Jest to bardzo bogate i złożone pojęcie, gdyż obok najbardziej rzucającego się w oczy komponentu poznawczego, czyli uświadamiania sobie czegoś, czego wcześniej się nie wiedziało, zawiera także komponent etyczny, co wynika z możliwości thumaczenia portugalskiego terminu consciência zarówno jako świadomość, jak i sumienie. To sprawia, że budzenie świadomości staje się w antropologii Freirego jednocześnie budzeniem sumienia, uświadamianiem sobie dobra i zła moralnego. Ale to jeszcze nie wyczerpuje znaczenia portugalskiego słowa conscientização. Analiza tekstów brazylijskiego pedagoga skłania do interpretacji budzenia świadomości również jako budzenia podmiotowości. Pojawia się tu wątek metafizyczny, wyraźne odniesienie do odzyskiwania tożsamości czy wręcz do odzyskiwania istnienia, o ile poprzez istnienie rozumiemy funkcjonowanie na pewnym poziomie kultury, właściwej dla ludzi jako osób. Dzięki temu procesowi jednostka przestaje być przedmiotem zanurzonym w świecie, a staje się podmiotem nawiązującym ze światem relacje.

Po wyjaśnieniu, w jaki sposób rozumiem tytuł tego artykułu, przechodzę do zwięzłej zapowiedzi, co jest jego zawartością oraz jaką tezę będę starała się w nim wykazać. W pierwszej części tekstu zajmuję się kwestią Freirowskiej antropologii, pokazując obecne w niej napięcie między naturą a kulturą. W drugiej części omawiam rolę edukacji w budzeniu refleksyjności, będącej warunkiem możliwości dochodzenia przez człowieka do podmiotowości. Całość kończę zwięzłym podsumowaniem, w którym wskazuję na osadzenie myśli Freirego wśród współczesnych paradygmatów pedagogiki, a także zastanawiam się nad możliwościami zastosowania narzędzi Freirowskich w badaniach problemów współczesnej polskiej edukacji.

\section{1. Życie $w$ świecie oraz życie ze światem}

Pedagogiczny projekt Paula Freirego sytuuje się w obszarze edukacji dorosłych, zaś jego kontekstem była i w jakimś stopniu wciąż pozostaje post- 
kolonialna struktura społeczeństwa brazylijskiego. Struktura ta sprawia, że ogromne rzesze najuboższych obywateli żyją w nieopisanej nędzy, na granicy natury i kultury, bardziej osadzeni w tej pierwszej, niż w drugiej. W Pedagogy of the Oppressed natrafiamy na fragment, w którym Freire relacjonuje spotkanie nauczyciela z dorosłymi, wiejskimi analfabetami:

Nierzadko mieszkańcy wsi zaczynają żywo omawiać w ramach edukacyjnych projektów jakiś generatywny temat, gdy nagle milkną i zwracają się do nauczyciela²: „Proszę nam wybaczyć, powinniśmy milczeć i pozwolić mówić Panu. Pan jest jedyną osobą, która coś wie, my nie wiemy niczego". Często podkreślają, że nie ma żadnej różnicy między nimi a zwierzętami; kiedy jednak uznają tę różnicę, to jest to z korzyścią dla zwierząt. „Żyją one w większej wolności niż my”3.

Nie jest to odosobniony tekst Freirego, w którym w taki właśnie sposób opisuje on życie najuboższych robotników rolnych, banitów, wykluczonych z dostępu do jakichkolwiek sfer kultury. W swoich listach do bratanicy, Anny, pisanych wiele lat później, Freire wspomina na przykład grupy odrzuconych, wegetujące na obrzeżach jego rodzinnego miasta, gdy był jeszcze chłopcem. Obraz tych na wpół dzikich ludzi nawiedzał go przez wiele kolejnych lat. Często Freirowskie opisy są odnoszone do przedstawień ludzkiej nędzy i poniżenia kreślonych przez Frantza Fenona, marksity i panafrykanisty, w książce Wyklęty lud ziemi z 1961 roku. Istnieje wiele podobieństw między postkolonialnym społeczeństwem Brazylii a postkolonialnymi społeczeństwami Afryki.

Stwierdzenie, że życie zwierząt jest lepsze od życia ludzi, musiało być wyjątkowo bolesne dla Freirego, który, wykształcony w duchu filozofii personalistycznej, w szczególny sposób podkreślał znaczenie godności osoby ludzkiej. Personaliści w opozycji do naturalistów uważają, że różnice pomiędzy zwierzęciem a człowiekiem są fundamentalne, a wynikają one z ludzkiej rozumności i duchowości, które osoba zawdzięcza Bogu, swemu Stwórcy. Obraz ludzkiego życia, które sytuuje się poniżej poziomu życia zwierzęcego, musiał budzić u Freirego radykalny sprzeciw, który z kolei kazał mu szukać najskuteczniejszych dróg przeciwstawienia się temu zjawisku. Taką drogą okazało się konstruowanie programów alfabetyzacyjnych.

\footnotetext{
2 Ang. educator (przypis thumacza polskiego).

3 Paulo Freire, Pedagogy of the Oppressed (London: Penguin Books, 1972), 39.
} 
Freire w Pedagogy of the Oppressed kreśli pożądany obraz człowieka jako istoty świadomej siebie i świata, w którym żyje. Pokazuje też, na czym polega różnica między osobą ludzką a zwierzęciem.

Dobrze pamiętamy - $\mathrm{i}$ jest to banalne, jak się wydaje - że człowiek jest jedyną spośród „niedokończonych” istot, która za przedmiot swojej refleksji bierze nie tylko swoje działania, lecz także samą swoją jaźń; ta zdolność odróżnia go od zwierząt, które są niezdolne do oddzielenia samych siebie od swojej działalności, i w ten sposób niezdolne do podejmowania nad nią refleksji. W tym pozornie powierzchownym rozróżnieniu leżą granice, które wytyczają działania każdej istoty w jej przestrzeni życiowej. Jako że poprzez swoją działalność zwierzęta poszerzają same siebie, rezultaty tej działalności także nie mogą być oddzielone od nich: zwierzęta nie potrafią ani wyznaczać sobie celów, ani nadawać dokonywanemu przez siebie przekształcaniu natury jakiegokolwiek znaczenia, które wykraczałoby poza samą naturę. Co więcej, „decyzja”, by podejmować tę działalność należy nie do nich, lecz do gatunków. Zwierzęta są zatem w fundamentalnym sensie, ,istotami w sobie"4.

Najubożsi zatem żyją w świecie, ale nie żyją ze światem, nie odnoszą się do niego w sposób świadomy i krytyczny. Jak to zmienić? Otóż należy obudzić ich świadomość. Analizując w książce Cultural Action for Freedom w 1972 roku pojęcie budzenia świadomości, Paulo Freire tak pisze:

Punktem wyjścia dla tego rodzaju analizy musi być krytyczne ujęcie człowieka jako bytu, który istnieje $w$ świecie oraz ze światem. Ponieważ podstawowym warunkiem „budzenia świadomości” jest to, że człowiek uczestniczący w tym procesie musi stać się podmiotem (to znaczy świadomym bytem), „budzenie świadomości”, podobnie jak edukacja, jest specyficznie i wyłącznie procesem ludzkim. To właśnie jako świadome byty ludzie nie tylko są $w$ świecie, ale także istnieją wraz ze światem, razem z innymi ludźmi. Jedynie ludzie jako byty „otwarte” są w stanie wznieść się na poziom złożonego działania, w którym równolegle mogą przekształcać świat poprzez swoje czyny, jak również chwytać i wyrażać rzeczywistość świata w swoim twórczym językus.

Budzenie świadomości zakłada uprzedni brak tejże lub jakieś jej zafałszowanie. Poprzez pojęcie fałszywej świadomości analizy Freirego zbliża-

4 Tamże, 70.

5 Paulo Freire, Cultural Action for Freedom (Harmondsworth: Penguin, 1972), 51. 
ją się do analiz marksistowskich. Podobnie jak w pismach Karola Marksa, tak też w pracach Paula Freirego powraca wątek fałszywej świadomości, która usypia ludzi i czyni ich bezsilnymi w obliczu dokonujących się niesprawiedliwości. Fałszywa świadomość jest rezultatem ideologicznych i edukacyjnych oddziaływań klasy ciemiężycieli, według Marksa - kapitalistów, według Freirego - kolonizatorów i ich współpracowników. Freire w książce Education for Critical Consciousness z 1980 roku wskazuje na dwa typy świadomości: świadomość naiwną, zwaną również magiczną, oraz świadomość krytyczną. Tylko ta druga jest osadzona w rzeczywistości. Pierwsza jest przykładem świadomości fałszywej, wypaczającej obraz rzeczywistości.

Sama świadomość jest oczywiście ważna, ale dla Freirego o wiele ważniejszy jest związek świadomości z działaniem. Świadomość naiwna lub magiczna prowadzi albo do niepodejmowania działań w ogóle, albo do działań irracjonalnych i fanatycznych. Swiadomość krytyczna wiedzie do działań przemyślanych i adekwatnych dla danej sytuacji. Jak odróżnić jedną i drugą świadomość? Freire przywołuje tu pojęcie przyczynowości. Tylko dzięki świadomości krytycznej ludzie są w stanie właściwie dostrzec przyczyny, które stoją za określonymi stanami rzeczy. Świadomość naiwna każe wierzyć, że rzeczywistość rozwija się wedle jakichś magicznych reguł, niezrozumiałych dla człowieka, i w rezultacie jego wpływ na otaczający świat jest żaden. Dotykamy tu zagadnienia sprawstwa. Tylko przywracając ludziom świadomość krytyczną, budząc w nich tę świadomość, możemy uczynić ich twórcami ich własnego życia, dać im poczucie podmiotowości.

Tak to ujmuje sam Paulo Freire w Pedagogy of the Oppressed:

Refleksja nad sytuacyjnością jest namysłem nad samym warunkiem istnienia: krytycznym myśleniem, poprzez które ludzie odkrywają, że nawzajem są „W sytuacji”. Tylko wówczas, gdy ta sytuacja przestanie się pojawiać jako niejasna wszechogarniająca rzeczywistość lub niepokojąca ślepa uliczka, i ludzie potrafią dojść do punktu, w którym dostrzegą w niej obiektywnie problematyczną sytuację - tylko wówczas będzie mogło pojawić się zaangażowanie. Ludzie wynurzaja się ze swojego zanurzenia i zyskują zdolność ingerowania w rzeczywistość, gdy zostaje ona odsłonięta. Ingerowanie w rzeczywistość sama historyczna świadomość - przedstawia zatem sobą krok do przodu w porównaniu z wynurzeniem, zaś wynika z obudzenia świadomości sytuacji. Budzenie świadomości jest pogłębieniem postawy świadomości charakteryzującej każde wynurzenie ${ }^{6}$.

\footnotetext{
${ }^{6}$ Freire, Pedagogy, 81.
} 
Dzięki obudzeniu świadomości człowiek staje się osobą i zyskuje poczucie, że nie tylko jest zależny od rzeczywistości, ale także potrafi tę rzeczywistość kształtować.

\section{Rola edukacji w budzeniu świadomości}

Zasługą Paula Freirego w obszarze pedagogiki było pokazanie, że budzenie świadomości jest możliwe przede wszystkim za pośrednictwem edukacji. Rzecz jasna nie można wykluczyć, że dorosły człowiek, żyjący dotychczas $w$ świecie, ale niezdolny do komunikowania się ze światem, poprzez jakieś nadzwyczajne wydarzenie uzyska dostęp do świadomości krytycznej. Takie rzeczy się zdarzają, ale jeśli objąć procesem budzenia świadomości całe grupy społeczne, to, zdaniem Freirego, musimy zwrócić się w stronę edukacji. Powiedzmy jednak od razu, że nie chodzi o edukację tradycyjną, ale alternatywną względem niej. Edukacja tradycyjna, zwana przez Freirego edukacją bankową, jest bowiem edukacją narzuconą przez kolonizatorów i ich współpracowników. Edukacja ta wzmacnia świadomość magiczną i odbiera motywację do działania. Sprawia, że uczniowie, niezależnie od tego, na jakim etapie kształcenia się znajdują, przyswajają sobie przekonanie, że status quo, w którym żyją, jest nienaruszalne, że nic nie zależy od nich. Dopiero edukacja alternatywna, którą Freire nazywa edukacją stawiającą problemy, może stanowić antidotum na tę beznadziejną sytuację.

Ten wątek analiz Freirego jest najbardziej znany, więc nie będę go w tym punkcie analizowała. Zresztą nie chodzi w tym artykule o rodzaje edukacji wyodrębnione przez brazylijskiego pedagoga, ale o złożony proces budzenia świadomości jako warunek dochodzenia do podmiotowości.

Paulo Freire zauważa, że warunkiem przekształcenia świadomości uciśnionych jest wejście z nimi w dialog. Przywołuje w związku z tym obraz nauczyciela/ucznia oraz ucznia/nauczyciela. W procesie edukacyjnym role nauczyciela i ucznia nakładają się na siebie, tak jak niepiśmienni dorośli uczą się od swoich nauczycieli, tak też ci drudzy uczą się od swoich uczniów. Ta wzajemna wymiana, osadzona głęboko w koncepcji dialogu, sprawia, że najbiedniejsi nie przyswajają sobie obrazu świata przynoszonego im z zewnątrz, ale docierają do obrazu świata istniejącego realnie w ich życiu. Dzięki przyjęciu tej perspektywy mogą oni dostrzec wiele aspektów rzeczywistości, które dotychczas były przed nimi zakryte. Freire tak o tym pisze w Pedagogy of the Oppressed: 
Uciśnieni muszą zobaczyć przykłady bezbronności uciskającego, tak by mogli zacząć dochodzić do przeciwnego przekonania. Zanim to nastąpi, ciągle będą zniechęceni, zastraszeni i bici (por. Revolution in the Revolution Debray'a). Tak długo jak uciśnieni pozostają nieświadomi przyczyn swojej kondycji, fatalistycznie ,akceptują” swój wyzysk. Dodatkowo, wykształcają w sobie zdolność do reagowania w pasywny i wyalienowany sposób, gdy muszą się skonfrontować z koniecznością walki o swoją wolność i samoafirmację. Powoli jednak starają się podejmować próby buntu. Pracując nad wyzwoleniem, nie można ani tracić z oczu tej pasywności, ani przeoczyć momentu przebudzenia ${ }^{7}$.

Dzięki edukacji najubożsi uświadamiają sobie, że stanowią integralną część społeczeństwa, że nie są wyrzutkami, wegetującymi na jego marginesie, istotami, które w opinii ciemiężycieli zasługują na los niewiele lepszy od zwierząt. W rezultacie wielowiekowej kolonizacji niepiśmienni chłopi pogodzili się ze stwierdzeniem, że nie ma dla nich miejsca w społeczeństwie.

Prawda natomiast jest taka, że uciśnieni nie są marginesem, nie są ludźmi żyjącymi „poza” społeczeństwem. Zawsze znajdowali się wewnątrz - wewnątrz struktury, która uczyniła z nich ,istoty dla innych”. Rozwiązaniem nie jest „zintegrowanie” ich w strukturze ucisku, lecz przekształcenie tej struktury, tak by mogli się oni stać „istotami dla siebie”. Takie przekształcenie oczywiście podważyłoby cele uciskających; dlatego używają oni bankowej koncepcji edukacji, by uniknąć zagrożenia płynącego z budzenia świadomości uczniów ${ }^{8}$.

Paulo Freire wielokrotnie powtarza, że przeprowadzenie projektu edukacyjnego o tak dużym rozmachu, przekształcającego tradycyjną koncepcję kultury, wymaga nadzwyczajnej determinacji ze strony nauczycieli. W istocie nie może być on przeprowadzony przez zwykłych nauczycieli, zatrudnianych wcześniej przez kolonizatorów i ich następców. Nauczyciele alfabetyzacji muszą być jednocześnie politycznymi liderami, przedstawicielami przywództwa rewolucyjnego. Radykalizm tych przekonań, utrzymywanych przez Freirego zwłaszcza na pierwszym etapie jego twórczości, czyni zasadnym pytanie o różnicę między edukacją a indoktrynacją. Czy w imię edukacji niepiśmiennych dorosłych nie dążymy do przekształcenia ich w rewolucjonistów? Brazylijski pedagog zaprzecza jednak takiemu rozumieniu edukacji.

\footnotetext{
7 Tamże, 40.

8 Tamże, 48.
} 
Właściwą metodą, jaką rewolucyjne przywództwo powinno stosować podejmując zadanie wyzwalania, nie jest zatem ,,propaganda wyzwalania”. To przywództwo nie może też jedynie ,zaszczepić” w uciśnionych wiary w wolność, myśląc że w ten sposób zdobędzie ich zaufanie. Właściwa metoda polega na dialogu. Przekonanie po stronie uciśnionych, iż muszą walczyć o swoje wyzwolenie, nie jest darem przekazanym im przez rewolucyjne przywództwo, lecz wynikiem ich własnego przebudzenia świadomości?

W przekonaniu Freirego rolą nauczycieli nie powinno być przekazywanie dorosłym uczniom obrazu świata właściwego dla tychże nauczycieli, ale stworzenie takich warunków, aby każdy uczeń dotarł do swojego własnego obrazu świata, odpowiadającego z jednej strony rzeczywistości, z drugiej jego własnej wrażliwości. W Pedagogy of the Oppressed oraz w wielu innych tekstach Freire przedstawia kolejne etapy procesu alfabetyzacji dorosłych, relacjonuje praktykę prowadzenia zajęć z nimi. Nie będę w tym miejscu zajmowała się tymi dydaktycznymi analizami, były one już wielokrotnie podejmowane. Dwoma kluczowymi pojęciami są dla Freirego w tym obszarze tematy generatywne oraz uniwersum tematyczne.

Równie właściwy dla metodologii tematycznego badania oraz edukacji stawiającej problemy jest wysiłek przedstawiania znaczących wymiarów kontekstowej rzeczywistości jednostki. Analiza tej rzeczywistości umożliwi jednostce rozpoznanie interakcji rozmaitych komponentów. Jednocześnie, znaczące wymiary, które z kolei tworzą części pozostające w interakcji, powinny być postrzegane jako wymiary całej rzeczywistości. W ten sposób krytyczna analiza jakiegoś znaczącego egzystencjalnego wymiaru umożliwia przyjęcie nowej, krytycznej postawy wobec sytuacji granicznych. Postrzeganie i rozumienie rzeczywistości zostają skorygowane i nabierają nowej głębi. Gdy analiza generatywnego tematu mieszczącego się w minimalnym uniwersum tematycznym (to znaczy w obrębie generatywnych tematów pozostających ze sobą w interakcji) jest przeprowadzana zgodnie z metodologią budzenia świadomości, wówczas wprowadza lub zaczyna wprowadzać ludzi w krytyczną formę myślenia o swoim świecie ${ }^{10}$.

\footnotetext{
9 Tamże, 42.

${ }_{10}$ Tamże, 76.
} 


\section{Zakończenie}

Freirowski program alfabetyzacji dorosłych osadzony jest w konkretnej antropologii, w której z jednej strony podkreśla się przyrodzoną i niezbywalną godność osoby ludzkiej, z drugiej uwikłanie człowieka w klasowe stosunki społeczne, które stają się źródłem naiwnej i mitycznej świadomości jednostki. Połączenie obu doświadczeń staje się podstawą pedagogii wyzwolenia, ściśle związanej z teologią wyzwolenia, o której wspomniałam na wstępie tego artykułu.

Jak należałoby usytuować dociekania Freirego w kontekście współczesnej, wieloparadygmatycznej pedagogiki? Sądzę, że w oczywisty sposób mieści się ona w obszarze pedagogiki alternatywnej oraz edukacji dorosłych. Przykładem eksploracji Freirowskich koncepcji w obszarze tych dwóch podejść jest praca Marii Czerepaniak-Walczak pt. Pedagogika emancypacyjna. Rozwój świadomości krytycznej człowieka.

Jeżeli chodzi o filozofię edukacji, to bez wątpienia koncepcji Freirego najbliżej jest do pedagogiki personalistycznej. Natomiast z punktu widzenia socjologii edukacji sytuuje się ona w paradygmacie teorii konfliktu, który tradycyjnie łączony jest z analizami Karola Marksa i jego uczniów. Związek personalizmu z marksizmem może być zaskakujący w kontekście kultury polskiej, ale z pewnością nie był taki w kontekście kultury południowoamerykańskiej. Co więcej, również wśród francuskich twórców personalizmu, przede wszystkim u Emmanuela Mouniera, można dostrzec wyraźne powinowactwa między tymi dwoma podejściami. Dla Mouniera kluczowe było zaangażowanie $\mathrm{w}$ przekształcanie świata $\mathrm{w}$ celu uczynienia zeń miejsca przyjaznego dla człowieka. Myśliciel francuski był otwarty na współpracę katolików z marksistami, o ile ma ona pomóc w osiągnięciu tego celu. Dokładnie taki sam cel przyświecał Freiremu. Wydaje się, że o ile można by wpisać koncepcję budzenia świadomości w nurt polskiej pedagogiki personalistycznej, a także w nurt współczesnych, pedagogicznych analiz klasowych, o tyle przywołanie obu tych wątków razem byłoby dla pedagogów czymś mało zrozumiałym.

Interesujący wątek związany z tym tropem można znaleźć w tekście ks. Józefa Tischnera pt. Teologia wyzwolenia a etyka solidarności. Tekst ten był wykładem wygłoszonym przez polskiego duchownego w Caracas podczas kolokwium w 1989 roku. Tischner krytycznie odnosi się w nim do teologii wyzwolenia, wskazując, że tym, co odróżnia ją od etyki solidarności, jest pozytywny stosunek do rewolucji oraz chęć takiego przekształcenia etyki, aby 
otwierała ona drogę tejże rewolucji. Solidarność tymczasem chce zaszczepić etykę w świecie postrewolucyjnym. $Z$ pedagogicznego punktu widzenia krytyka Tischnera dotyka kwestii relatywnego charakteru norm moralnych i wychowania do tworzenia tych norm. Rewolucjoniści roszczą sobie prawo do konstruowania etyki zgodnie z własnymi przekonaniami, podczas gdy, zauważa Tischner, etyka niesie w sobie obraz wartości absolutnych, których nie można kwestionować. Jak w tym sporze usytuowałby się Paulo Freire? Jest to złożone pytanie. Z pewnością był on za rewolucją i rewolucyjną etyką, niemniej nie postulował zastąpienia ciemięzców uciśnionymi, lecz stworzenie nowego społeczeństwa opartego na szacunku dla każdego człowieka. Pomimo tego, że od wystąpienia Tischnera w Caracas upłynęło niemal trzydzieści lat, problem chrześcijańskich odniesień teologii i pedagogii wyzwolenia wciąż pozostaje aktualny i budzi wiele pytań ${ }^{11}$.

Pozostawmy jednak tę kwestię i powiedzmy, że pedagogika Freirego $\mathrm{z}$ pewnością nie mieści się $\mathrm{w}$ nurcie analiz postmodernistycznych. Chociaż wiele analiz tego rodzaju ujawnia ścisłe związki z neomarksizmem, to jednak w przypadku koncepcji brazylijskiego pedagoga kluczowa jest jej oświeceniowa orientacja, wraz z centralnym dla niej przekonaniem o możliwości dotarcia do prawdy o człowieku. Elementem takiego ugruntowania koncepcji jest także na wskroś optymistyczna wizja edukacji jako racjonalnego i skutecznego narzędzia zmiany społecznej. Chociaż myśl Freirego jest często łączona z pedagogiką krytyczną, to jednak jest od niej bardzo oddalona-Freire poprzez edukację nie chce w pierwszej kolejności dekonstruować społeczeństwa, ale rekonstruować je na gruncie nowej racjonalności, odwołującej się do solidarności i miłości. Jego projekt jest w pełni meliorystyczny. Jestem świadoma, że taka opinia nie znajduje potwierdzenia w pracach wielu polskich pedagogów, którzy interpretują myśl Freirego w kategoriach pedagogiki krytycznej. Dobrym przykładem takiego podejścia są prace Piotra Stańczyka i Pawła Rudnickiego.

Czy, a jeśli tak, to w jaki sposób, można by we współczesnej polskiej pedagogice wykorzystać Freirowskie analizy, zwłaszcza jego koncepcję budzenia świadomości? To bardzo interesujące pytanie. Sądzę, że pewną wskazówką może być dla nas stopniowe wycofywanie się brazylijskiego pedagoga z radykalnych, marksistowskich analiz społeczeństwa i rewolucyjnych dróg jego przemiany. Wydaje się, że wraz z upływem lat sam Freire stopniowo dochodził do wniosku, że tego rodzaju analizy są skrajne i niekorzystne

${ }^{11}$ Dziękuję dr hab. Piotrowi Kostyło, prof. UKW, za inspirującą dyskusję na temat tekstu ks. Józefa Tischnera pt. Teologia wyzwolenia a etyka solidarności. 
dla zasadniczej, dydaktycznej części jego koncepcji. Były one niekorzystne, gdyż rzucały niejako cień swojego radykalizmu na programy alfabetyzacyjne, które same z siebie radykalne nie były, a już z pewnością nie miały charakteru rewolucyjnego. Budzenie świadomości jest procesem uniwersalnym, niezwiązanym ściśle z kontekstem walki klasowej.

Patrząc na to $z$ tego punktu widzenia, można powiedzieć, że budzenie świadomości jest integralnym elementem wszelkiej działalności pedagogicznej, poprzez którą chcemy zachęcić adresatów naszych programów do uświadomienia sobie ich wartości dla polepszenia jakości ich życia. Takie jest też moje doświadczenie w obszarze edukacji zdrowotnej, którą zajmuję się w ostatnich latach.

\section{Reflexion as a Ground for Empowerment. Following Paulo Freire's Anthropology (Summary)}

The article deals with a question of reflexion as a condition for the awakening of human empowerment, in Paulo Freire's anthropological view. The awakening of conscience as one of the key concepts worked out by the Brazilian pedagogue, is conceived here as the awakening of human empowerment. A subject is a person who understands culture in which he/she lives and with which he/she establishes relationships. The opposite attitude characterizes a person who believes that he/she is a mere passive element of nature. A difference between nature and culture, as defined by Freire, is also analyzed in the text. Then, the value of education as the main factor contributing to the awakening of conscience is shown. The article is concluded with a short presentation of the multi-layered Freirean inspirations for pedagogy.

Keywords: Paulo Freire; the awakening of conscience; identity; anthropology; education.

\section{Refleksja jako podstawa podmiotowości. Według antropologii Paula Freirego (Streszczenie)}

Artykuł dotyczy kwestii refleksji jako warunku budzenia się podmiotowości człowieka w antropologicznej wizji Paula Freirego. Budzenie świadomości jako jedno z kluczowych pojęć wypracowanych przez brazylijskiego pedagoga jest rozu- 
miane w niniejszym tekście jako budzenie podmiotowości ludzkiej. Podmiotem jest osoba rozumiejąca kulturę, w której żyje, i nawiązująca z nią relacje, w przeciwieństwie do osoby, która jest przekonana, że jest biernym elementem natury. W tekście jest analizowana różnica między naturą i kulturą w ujęciu antropologii Freirego. Następnie pokazane jest znaczenie edukacji jako głównego czynnika służącego budzeniu świadomości. Artykuł zamyka krótkie przedstawienie wielowątkowych inspiracji myśli Freirego dla pedagogiki.

Słowa kluczowe: Paulo Freire; budzenie świadomości; tożsamość; antropologia; edukacja.

\section{Bibliografia}

Czerepaniak-Walczak, Maria. Pedagogika emancypacyjna. Rozwój świadomości krytycznej człowieka. Gdańsk: GWP, 2006.

Fenon, Frantz. Wyklęty lud ziemi. Tłum. Hanna Tygielska. Warszawa: PIW, 1985.

Freire, Paulo. Cultural Action for Freedom. Harmondsworth: Penguin, 1972.

Freire, Paulo. Education for Critical Consciousness. New York: Continuum, 1980.

Freire, Paulo. Letters to Cristina. Reflections on My Life and Work. New York and London: Routledge, 1996.

Freire, Paulo. Pedagogy in Process. The Letters to Guinea-Bissau. New York: The Seabury Press, 1978.

Freire, Paulo. Pedagogy of Hope: Relieving Pedagogy of the Oppressed. New York: Continuum, 1994.

Freire, Paulo. Pedagogy of the City. New York: Continuum, 1993.

Freire, Paulo. Pedagogy of the Oppressed. London: Penguin Books, 1972.

Freire, Paulo. The Politics of Education. Culture, Power, and Liberation. Houndmills, Basingstoke, Hampshire and London: Macmillan Publishers Ltd, 1985.

Kostyło, Hanna. „Dwa sposoby (rozumienia) alfabetyzacji”. Kultura i Edukacja 1 (2010): 58-69.

Kostyło, Hanna. „Przesłanie ‘Pedagogii uciśnionych’ Paula Freire”. Forum Oświatowe 2 (2011): 7-26.

Rudnicki, Paweł. „Działanie jako forma oporu wobec ideologii dominujących: o (nie)skuteczności radykalnej myśli pedagogicznej”. W: Władza, sens, działanie: studia wokół związków ideologii i edukacji, red. Paweł Rudnicki, Marcin Starnawski, Mirosława Nowak-Dziemianowicz, 407-428. Wrocław: Wydawnictwo Naukowe Dolnośląskiej Szkoły Wyższej, 2012. 
Stańczyk, Piotr. „Pedagogika radykalna Paulo Freire wobec różnic społecznych: rzecz o edukacji ludowej”. Człowiek - Teraźniejszość - Edukacja 1 (2016): $37-51$.

Tischner, Józef. „Teologia wyzwolenia a etyka solidarności”. W: Józef Tischner, Etyka solidarności. Homo sovieticus, 214-230. Kraków: Znak, 2005.

Zielińska, Hanna. „Dialog Martina Bubera z Paulo Freire”. W: Zaufanie i zrozumienie. Verständnis und Vertrauen, red. Friedrich W. Busch, Piotr Petrykowski, 79-87. Toruń: Universitas Nicolai Copernici; Oldenburg: Carl von Ossietzky Universität Oldenburg, 2001.

Zielińska, Hanna. „Freirowska koncepcja edukacji w sytuacji zmiany społecznej”. W: Edukacja alternatywna, nowe teorie, modele badań i reformy, red. Jacek Piekarski, Bogusław Śliwerski, 27-45. Kraków: Impuls, 2000.

Zielińska, Hanna. „Noam Chomsky o antyedukacyjnej funkcji globalnej amerykanizacji”. Forum Oświatowe 2 (2001): 5-32.

Zielińska, Hanna. „Paulo Freire i jego rozumienie sytuacji edukacyjnej”. W: Nieobecne dyskursy, t. VI, red. Zbigniew Kwieciński, 215-230. Toruń: UMK, 2000.

Zielińska-Kostyło, Hanna. „Humanistyczne źródła pedagogiki emancypacyjnej”. AUNC. Socjologia Wychowania 360 (2003): 185-196.

Zielińska-Kostyło, Hanna. „Pedagogika emancypacyjna”. W: Pedagogika. Podręcznik akademicki, t. I, red. Zbigniew Kwieciński, Bogusław Śliwerski, 394-414. Warszawa: PWN, 2003.

Zielińska-Kostyło, Hanna. Rekonstrukcjonistyczne koncepcje zmiany społecznej poprzez edukację. Antropologia pedagogiczna T. Bramelda. Toruń: Wydawnictwo UMK, 2005. 